\title{
PARATOPIA E METAENUNCIAÇÃO NO DISCURSO TEOLÓGICO
}

Candido Ferreira de SOUZA JUNIOR Micheline Mattedi TOMAZI

\section{Introdução}

Este capítulo tem como tema o estudo do discurso teológico, na medida em que entendemos a Teologia como produtora de discurso e verificamos que ela também se abre para outros espaços de inteligibilidade de seu campo, acata a interdisciplinaridade com a Linguística e outras áreas das ciências sociais e humanas, tornando mais efetiva a compreensão dos fenômenos estudados por ela.

A Análise do Discurso de linha francesa (AD) tem contribuído decisivamente para a análise de textos dos mais variados campos sociais, incluindo-se aí os campos religioso e teológico. Lembrando que, na perspectiva da $\mathrm{AD}$, o discurso é entendido como a intricação de um texto e um lugar social, ou seja, seu objeto não é 
nem a organização textual, nem a situação de comunicação, mas aquilo que os une por intermédio de um dispositivo de enunciação específico. Sendo assim, importa-nos compreender os efeitos de sentido mobilizados no interior de cada discurso, compreendendo o papel fundamental que a linguagem ocupa na sociedade e na resolução de seus conflitos.

Nos últimos anos, Maingueneau trouxe à luz a discussão acerca dos discursos constituintes, agrupando os discursos que tematizam sua própria constituição, aqueles discursos primeiros, fundadores, que legitimam diversos gêneros de discurso em circulação na nossa sociedade. É então, com base no aporte teórico-metodológico proposto por Maingueneau (1997, 2000, 2001, 2005, 2006, 2007a, 2007b, 2007c, 2008, 2009, 2010, 2014, 2015, 2016), que se insere numa perspectiva enunciativo-discursiva, que apreendemos, aqui, o gênero de discurso parábola como discurso constituinte teológico.

O objetivo deste capítulo é compreender o funcionamento da paratopia e da metaenunciação no interior do discurso teológico, materializado em seu gênero parábola. A paratopia, segundo Maingueneau (2009), pode manifestar-se em dois níveis, ou seja, no nível dos discursos constituintes em sua abrangência e no nível do produtor do texto de cada um dos discursos constituintes. Nossa reflexão enfoca esse segundo nível, na medida em que o produtor do discurso constituinte teológico apaga sua identidade para dar voz a uma instância superior, assumindo uma condição paratópica constitutiva desse tipo de discurso. No caso da metaenunciação, entendemos que esta funciona como um processo pelo qual o sujeito produtor comenta aquilo que diz, construindo um texto sem a possibilidade de atribuí-lo totalmente a si próprio, problematizando essa sua condição de criador, para dar lugar a um metaenunciador, destituindo o sujeito do domínio de seu dizer. 
Selecionamos para análise o discurso "Os Dois Devedores", registrado no evangelho de Lucas. No que se refere aos procedimentos metodológicos, adotamos um percurso de análise, baseado naquilo que preconiza a $\mathrm{AD}$ e que organizamos da seguinte forma: em primeiro lugar, recuperamos as condições sócio-históricas e culturais de produção do discurso "Os Dois Devedores"; em segundo lugar, operacionalizamos as categorias de paratopia e metaenunciação, a fim de atingir os objetivos propostos. Damos especial atenção à cenografia, ao código linguageiro e aos temas teológicos, uma vez que eles se tornam fundamentais para a compreensão do discurso.

O capítulo se divide da seguinte maneira: após essas considerações iniciais, na primeira seção, discutimos o discurso teológico como pertencente à categoria dos discursos constituintes, baseando-nos nos apontamentos feitos por Maingueneau; na segunda seção, discutimos as noções de paratopia, metaenunciador e hiperenunciador, e seu funcionamento nas parábolas em Lucas; a seção seguinte apresenta a análise da parábola com base no aporte teórico-metodológico apresentado nas seções anteriores; a última seção traz algumas conclusões sobre a análise da parábola "Os Dois Devedores”, enfocando a paratopia e a metaenunciação como elementos estabilizadores do processo criativo do discurso.

\section{O discurso teológico como discurso constituinte}

Ao elencar os discursos considerados por ele constituintes, Maingueneau (2000) aponta quatro tipos de discurso: o científico, o filosófico, o religioso e o literário. Nesse quadro, o discurso teológico situa-se dentro do campo religioso. No entanto, adotamos aqui um posicionamento diferenciado a respeito do discurso teo- 
lógico e do discurso religioso, pois que se tratam, na nossa ótica, de discursos diferentes.

Para nós, o discurso religioso se configura como um discurso institucional. Sendo assim, o enunciador, nesse tipo de discurso, está ligado à instituição que ele pertence e/ou representa. Já o discurso teológico está ligado ao transcendente, ao campo mítico. A legitimidade do enunciador advém do próprio Deus, como fonte fundadora do discurso. Consideramos, assim, o texto bíblico como discurso teológico, aquele que é autoconstituinte, que funda a si próprio e não admite, pela sua própria natureza de constituência, ser influenciado por nenhum outro. Já o discurso religioso é aquele que se configura, in essentia, por meio do interdiscurso teológico, apropriando-se deste para validar suas proposições. Ou seja, uma parábola bíblica, como é o caso da analisada aqui, apreendemos como discurso teológico, enquanto um sermão pastoral, por exemplo, pregado em uma comunidade cristã aos domingos, consideramos como discurso religioso. O sermão só será validado pela comunidade discursiva que o legitima na medida em que basear seus enunciados no discurso teológico, no texto bíblico. Na verdade, para garantir a adesão do seu co-enunciador, ele precisa da autoridade do discurso teológico, que está ligado, in essentia, ao próprio Deus.

Segundo Erickson (1997, p. 16),

A Teologia é biblica. Ela toma seu conteúdo principal das Escrituras do Antigo e do Novo Testamento [...] é primeiramente a Palavra de Deus que constitui o conteúdo da Teologia (ERICKSON, 1997, p. 16). 
Discurso teológico e discurso religioso são diferentes tanto na organização interna e configurações discursivas, como em relação às suas condições de produção, uma vez que exigem marcas linguísticas específicas e mecanismos formais que explicitem o funcionamento de cada um dos discursos. Também diferem na forma como delimitam sua identidade e, assim, estabelecem suas fronteiras. $\mathrm{O}$ entendimento dessas diferenças torna-se fundamental na perspectiva de leitura desses discursos, uma vez que se estabelecem pactos necessários, entre enunciador e co-enunciadores, no processo de construção de sentidos.

A conceituação de discurso teológico e discurso religioso é, evidentemente, complexa, no entanto, a fim de deixar claro o nosso posicionamento, apresentamos, a seguir, algumas propriedades que julgamos fundamentais e que diferem o discurso teológico do discurso religioso.

O discurso teológico possui uma relação intrínseca com Deus, seu foco é a pessoa de Deus, enquanto o discurso religioso foca no "relacionamento" com a divindade. O discurso teológico define-se como aquele em que há uma compreensão ampla de Deus. Busca entender quem é Deus, sua natureza, seus atributos, sua atuação no universo etc. Já o discurso religioso, a partir do teológico, busca a adesão do seu co-enunciador apresentando-se como o único legítimo para levá-lo a um "relacionamento" com o transcendente. Logo, o discurso religioso se constitui como uma espécie de "porta-voz" do discurso teológico. Ou seja, para que o discurso religioso tenha sentido, ele precisa se constituir pelos sentidos do "já-dito" no discurso teológico. Esse interdiscurso teológico "migra” para o discurso religioso legitimando-o e, no interior deste, opera novos efeitos de sentido. 
Para o teólogo Bruce Milne (1996), a autoridade final do discurso teológico é o próprio Deus, que se revela a nós pelas Escrituras.

A fonte final de autoridade, porém, é o próprio Deus trino, que se revelou a nós através das palavras da Bíblia [...] Nosso conhecimento de Deus vem através da Bíblia [...] A Bíblia deve ser recebida como Palavra de Deus para nós, reverenciada e obedecida como tal. Quando nos submetemos à sua autoridade, nos colocamos sob a autoridade do Deus vivo que se revela a nós (MILNE, 1996, p. 18).

O discurso teológico baseia-se na fé, enquanto o discurso religioso baseia-se nos ritos. $\mathrm{O}$ discurso teológico está articulado, metodologicamente, com a fé, que se torna sua propriedade fundamental. Uma vez que o teológico tem seu foco em Deus, somente os que creem podem alcançar a verdadeira dimensão dos seus enunciados. Então, aquele que se aproxima do texto bíblico precisará crer na dimensão da "inspiração" das Escrituras para tomá-lo como texto sagrado e, por conseguinte, a expressão do próprio Deus. "De fato, sem fé é impossivel agradar a Deus, porquanto é necessário que aquele que se aproxima de Deus creia que ele existe e que se torna galardoador dos que o buscam" (Hebreus 11:6).

Já o discurso religioso adquire sua força nos ritos religiosos. Através dos ritos, o discurso religioso busca estabelecer as "regras" que validam o relacionamento do humano com a divindade. Essas regras serão estabelecidas e validadas pelo teológico, uma vez que o religioso busca se estabelecer como o seu fiel representante. 
O discurso teológico é perene e dogmático, enquanto o discurso religioso é adaptável ao ambiente sócio-histórico e cultural. Por se autoproclamar como a "Palavra de Deus", o teológico tende à perenidade e ao estabelecimento de dogmas que são imutáveis. Numa perspectiva tradicional exegética, o discurso teológico tende a ter um sentido fixo e já preestabelecido. As Escrituras são imutáveis e eternas, uma vez que o próprio Deus é imutável e eterno. "Deus é Espírito Infinito, sem fronteiras ou limites tanto quanto ao seu Ser como quanto aos Seus atributos, e cada aspecto e elemento de Sua natureza é infinito" (DOUGLAS, 1995, p. 406).

Já o religioso adquire sua relevância por se apresentar como o único legítimo para "interpretar" e "reinterpretar" as Escrituras e colocá-las ao alcance dos comuns dos mortais. É o que Maingueneau (2000) chama de quadro hermenêutico e que se torna uma das propriedades fundamentais dos discursos constituintes. O discurso teológico é o "arquitexto", "o monumento", enquanto o discurso religioso se materializa em gêneros "menos nobres", como sermões, livros devocionais, revistas e panfletos religiosos.

O discurso religioso, para se constituir, interage com o discurso teológico, constrói-se sobre ele, tomando-o como um interdiscurso, que, no interior de seu funcionamento, se re-significa, propiciando e delimitando possíveis interações (NASCIMENTO, 2009, p. 15).

O caráter adaptável do discurso religioso é facilmente percebido através dos gêneros do discurso. $O$ gênero sermão, por exemplo, hoje se "moderniza", a fim de se adaptar à internet e aos veículos de comunicação de massa. O sermão que antes era circunscrito ao templo, hoje é pregado na rádio e televisão, ao mesmo tempo em que é transformado em texto escrito, para que os fiéis 
possam consultá-lo na internet. Isso influi na sua estrutura e nos mecanismos de fala utilizados. Já os gêneros do discurso teológico são imutáveis. Um evangelho será sempre um evangelho, não pode sofrer alterações, sob o risco de colocar em xeque a sua autoridade. O mesmo ocorre com as epístolas, os salmos e os demais gêneros bíblicos. Ainda que as editoras bíblicas se empenhem em produzir versões com leitura mais fácil para o público atual, prevalecerá sempre a força do autógrafo original. $\mathrm{Na}$ verdade, quanto mais próximo for do autógrafo original, mais prestígio terá determinada versão do texto bíblico. Isso vale inclusive para as versões digitais, disponíveis na internet. Muda a forma de interação, mas o texto continua o mesmo. Sua autoridade reside na imutabilidade.

\section{Quadro 3 - Propriedades do discurso teológico e do discurso religioso}

\begin{tabular}{|c|c|}
\hline DISCURSO TEOLÓGICO & DISCURSO RELIGIOSO \\
\hline $\begin{array}{c}\text { É autoconstituinte, funda a si próprio. } \\
\text { Não admite ser influenciado por } \\
\text { nenhum outro discurso. }\end{array}$ & $\begin{array}{c}\text { Constitui-se através do interdiscurso teo- } \\
\text { lógico, apropriando-se deste para vali- } \\
\text { dar suas proposições. }\end{array}$ \\
\hline $\begin{array}{c}\text { Possui uma relação intrínseca com } \\
\text { Deus (quem é Deus, sua natureza, } \\
\text { seus atributos, sua atuação no uni- } \\
\text { verso). O enunciador legitima-se a } \\
\text { partir do próprio Deus. }\end{array}$ & $\begin{array}{c}\text { do humano com a divindade (apre- } \\
\text { senta-se como o único legítimo para } \\
\text { levaro humano a um "relacionamen- } \\
\text { to" com o transcendente). }\end{array}$ \\
\hline $\begin{array}{c}\text { Baseia-se na Fé (é preciso crer que Deus } \\
\text { existe). }\end{array}$ & $\begin{array}{c}\text { Baseia-se nos ritos (os rituais religiosos } \\
\text { conectam o humano com a divinda- } \\
\text { de). }\end{array}$ \\
\hline $\begin{array}{c}\text { É perene e dogmático (tende ao estabe- } \\
\text { lecimento de dogmas imutáveis). }\end{array}$ & $\begin{array}{c}\text { É adaptável às condições sócio-históricas } \\
\text { e culturais. }\end{array}$ \\
\hline
\end{tabular}




\section{Paratopia em Lucas e as instâncias enunciativas nas parábolas}

A paratopia se constitui numa propriedade fundamental para os discursos constituintes. Ao mesmo tempo em que são construídos em comunidades locais bem definidas, suas falas se legitimam através do Absoluto, que está para além da sociedade. É justamente isso que garante autoridade constituinte ao discurso. Essa localização paradoxal é percebida de forma clara no discurso teológico. Os "escritores" bíblicos recebem a denominação comum de hagiógrafos, termo grego derivado de hagios - santo / graphía escrita. São, portanto, os escritores santos ou escritores dos textos sagrados. São ao mesmo tempo seres humanos que pertencem a um contexto sócio-histórico definido, mas que produzem enunciados que transcendem toda e qualquer localidade. Eles falam em nome de Deus, dando voz a um "hiperenunciador".

De acordo com Maingueneau (2008), o conceito de hiperenunciador está ligado a um sistema que ele denomina "sistema de particitação", que funde "participar" e "citação" ao mesmo tempo. É diferente da citação tradicional, de um discurso citado, que geralmente envolve o recorte de um fragmento, a explicitação de sua fonte e a inserção em uma dada situação de comunicação. Maingueneau (2008) demonstra como esse "sistema de particitação" se desenvolve:

- O enunciado "citado" é um enunciado autônomo porque ele já o é originalmente ou porque foi previamente automatizado mediante sua extração do contexto;

- Essa "citação" deve ser reconhecida como tal pelo co-enunciador, sem que o enunciador indique sua fonte e nem mesmo deixe claro que ele efetua uma citação; 
- $\quad$ enunciador que cita mostra a sua adesão ao enunciado citado, que pertence àquilo que se poderia denominar de um "tesouro" de enunciados que circulam em determinada comunidade e se torna indissociável da própria comunidade;

- Esse "tesouro" e a comunidade correspondente recorrem a um hiperenunciador, cuja autoridade garante a validade dos enunciados, sua adequação aos valores e aos fundamentos de uma coletividade.

Para Maingueneau (2008), o hiperenunciador aparece como uma instância que, por um lado, garante a unidade e a validade da multiplicidade dos enunciados de um tesouro compartilhado por uma comunidade e, por outro, confirma os próprios membros da comunidade em sua identidade. O hiperenunciador é, então, a voz que se sobrepõe à voz do enunciador. É preciso que o enunciador apague-se, de alguma maneira, para mostrar que ele é apenas o "porta-voz" da fala de um Absoluto. Dessa forma, a problemática do "hiperenunciador" está sempre ligada à manifestação de um ethos discursivo que se constrói no processo de enunciação. “[...] As práticas de participação são assim ligadas a ethos discursivos característicos que cavam um desnivelamento enunciativo" (MAINGUENEAU, 2008, p. 109).

Maingueneau (2008) distingue dois grandes tipos de hiperenunciador. O primeiro, quando o hiperenunciador é individuado, como no caso do discurso teológico, o próprio Deus. Isso leva a uma hermenêutica clara em relação ao discurso: o que Deus quer nos dizer com isso? Já o segundo tipo é quando se trata de um sujeito universal, dóxico, que pode se materializar em provérbios, 
adágios, contos populares etc. Nesse caso, trata-se de uma instância mais responsável por uma memória do que por uma consciência. Resumindo, podemos concluir que o hiperenunciador se expressa por meio do enunciador, que se vê habitado por ele. Sua presença é perceptível pelo próprio processo constitutivo da enunciação (ethos discursivo), através de uma memória discursiva compartilhada por uma determinada comunidade, como um "tesouro", que funda a própria comunidade.

Essa categoria de hiperenunciador se inscreve, então, numa perspectiva ampla, que é o conjunto das instâncias de enunciação. Nesse quadro enunciativo, podemos falar em uma outra categoria, a de "metaenunciador". De acordo com Possenti (2000), os analistas do discurso chamam de metaenunciação ao processo pelo qual um enunciador comenta aquilo mesmo que ele diz. Os casos clássicos de metaenunciação são marcados por expressões como "para falar francamente..." ou "literalmente, quero dizer..." ou ainda "isto é, ...".

No entanto, quando pensamos as várias formas pelas quais o discurso encena o seu próprio processo de comunicação, percebemos a complexidade que a metaenunciação pode assumir. Segundo Authier-Révuz (1990), a metaenunciação estabelece uma negociação do sujeito em meio a toda a heterogeneidade constitutiva que caracteriza o discurso. Maingueneau (2008) cita, como exemplo, a imprensa escrita. Embora cada artigo escrito tenha um autor singular, existe uma instância enunciativa que vem a ser o próprio jornal e que transcende a multiplicidade dos artigos. É aquilo que caracteriza o "tom" de cada jornal, sua linha editorial. É comum dizer-se "saiu no Estadão" ou "deu na Folha". Dessa forma, percebemos que o jornal "fala" pela voz de cada jornalista ou articulista que nele escreve. Sendo assim, a instância enunciativa, que é o jornal, orquestra a sua própria enunciação através de múltiplas 
vozes. É mais do que comentar, mas é articular a própria enunciação, a fim de atingir os objetivos propostos. A essa instância, Maingueneau (2008) denomina "metaenunciador". "Poder-se-ia opor, por exemplo, esse 'metaenunciador' - que seria o jornal em relação a cada artigo que ele contém" (MAINGUENEAU, 2008, p. 111).

Percebemos esse processo também no discurso constituinte teológico, em especial nos evangelhos. A fim de atingir os seus objetivos teológicos, cada evangelista orquestra a sua própria enunciação através de múltiplas vozes, seja a voz de Jesus, dos discípulos, dos líderes religiosos da época ou dos grupos sociais que interagem no discurso. Sendo assim, o evangelista opera como um "metaenunciador", articulando a própria enunciação através das vozes dos sujeitos que ele mesmo cria em seus enunciados. É comum pregadores citarem textos bíblicos afirmando: "conforme vemos em Lucas, Jesus diz..." ou ainda, "de acordo com Mateus, Jesus nos ensina..., ou seja, claramente temos uma instância enunciativa, o evangelista, que se vale da voz de Jesus ou de outros sujeitos que aparecem em seus enunciados, a fim de atingir seus propósitos discursivos.

Pensando o texto de Lucas, em especial os do gênero de discurso parábola, temos então essa problemática constitutiva: primeiro, Lucas é um escritor humano escrevendo um texto divino, no caso, um evangelho; segundo, em si tratando especificamente das parábolas, elas foram narradas originalmente por Jesus, mas é Lucas quem faz seu registro escrito. Para compreender a equação que se desenvolve na enunciação precisamos entender, então, a posição dos atores dentro do discurso constituinte teológico:

- Jesus é o Cristo, o Verbo encarnado. Posição paratópica in essentia: $100 \%$ homem e $100 \%$ Deus. O divino e o humano 
se encontrando em uma só pessoa;

- Lucas é o hagiógrafo, aquele que escreve sob a inspiração do Espírito Santo. Também ocupa posição paratópica, a de pertencer ao mundo dos mortais (ele é apenas homem), mas, ao mesmo tempo, ser a voz por meio da qual se expressa a divindade.

Percebemos, então, uma dupla paratopia, a do Cristo que narra as parábolas originalmente e a de Lucas, o hagiógrafo que faz o registro literário anos mais tarde. A estabilização criadora dos enunciados em Lucas se configura pelo processo de "metaenunciação". Ao orquestrar a sua própria enunciação utilizando a voz de Jesus, a instância enunciativa, Lucas, busca justamente dar maior autoridade aos seus enunciados. As parábolas na boca de Lucas não teriam a mesma eficácia quanto na boca de Jesus. Ao fazer o registro das parábolas narradas por Jesus, sendo este o próprio Cristo, o Verbo encarnado, Lucas, na realidade, opera como um "metaenunciador", articulando a sua própria enunciação. Ao fazer isso, ele legitima os seus enunciados perante a comunidade discursiva que mobiliza o discurso teológico e faz emergir um corpo que dá voz ao "hiperenunciador" que funda o discurso constituinte teológico, o próprio Deus. Esta metaenunciação se torna parte constitutiva do discurso teológico em seu gênero parábola, fazendo com que a voz de cada ator seja construída no processo de leitura, seja a voz de Jesus, dos líderes religiosos da época ou dos grupos sociais que interagem no discurso. As parábolas em Lucas são, portanto, mais do que simples estórias contadas por um mestre a seus discípulos, elas são a expressão do Deus cristão falando diretamente com a humanidade. Nisso reside a sua força e o seu poder de perpetuar-se através das gerações. 


\section{Discurso "Os dois devedores"}

O evangelho de Lucas é o terceiro dos quatro evangelhos do Novo Testamento e registra, em 24 capítulos, a vida e obra de Jesus, desde o nascimento, em Belém, até à morte e ressurreição em Jerusalém. $\mathrm{O}$ discurso "Os Dois Devedores" situa-se no capítulo 7 e faz parte da seção em que Lucas narra os fatos do ministério público de Jesus acontecidos na Galiléia. Essa seção inicia-se em Lucas 4:14 e se estende até Lucas 9:50, registrando fatos como a escolha dos doze apóstolos, o sermão das bem-aventuranças, diversas curas e milagres. No caso específico desse discurso, temos Jesus sendo convidado para jantar na casa de um líder religioso da época, pertencente ao grupo dos fariseus, conforme consta em Lucas 7:36-50:

36 Convidou-o um dos fariseus para que fosse jantar com ele. Jesus, entrando na casa do fariseu, tomou lugar à mesa.

37 E eis que uma mulher da cidade, pecadora, sabendo que ele estava à mesa na casa do fariseu, levou um vaso de alabastro com unguento;

38 e, estando por detrás, aos seus pés, chorando, regava-os com suas lágrimas e os enxugava com os próprios cabelos; e beijava-lhe os pés e os ungia com o unguento.

39 Ao ver isto, o fariseu que o convidara disse consigo mesmo: Se este fora profeta, bem saberia quem e qual é a mulher que the tocou, porque é pecadora.

40 Dirigiu-se Jesus ao fariseu e lhe disse: Simão, uma coi- 
sa tenho a dizer-te. Ele respondeu: Dize-a, Mestre.

41 Certo credor tinha dois devedores: um the devia quinhentos denários, e o outro, cinquenta.

42 Não tendo nenhum dos dois com que pagar, perdoou-lhes a ambos. Qual deles, portanto, o amará mais?

43 Respondeu-lhe Simão: Suponho que aquele a quem mais perdoou. Replicou-lhe: Julgaste bem.

44 E, voltando-se para a mulher, disse a Simão: Vês esta mulher? Entrei em tua casa, e não me deste água para os pés; esta, porém, regou os meus pés com lágrimas e os enxugou com os seus cabelos.

45 Não me deste ósculo; ela, entretanto, desde que entrei não cessa de me beijar os pés.

46 Não me ungiste a cabeça com óleo, mas esta, com bálsamo, ungiu os meus pés.

47 Por isso, te digo: perdoados lhe são os seus muitos pecados, porque ela muito amou; mas aquele a quem pouco se perdoa, pouco ama.

48 Então, disse à mulher: Perdoados são os teus pecados. 49 Os que estavam com ele à mesa começaram a dizer entre si: Quem é este que até perdoa pecados?

50 Mas Jesus disse à mulher: A tua fé te salvou; vai-te em paz. 
Percebemos que, de início, o enunciador organiza o discurso em uma cenografia de um jantar especial oferecido a um convidado ilustre. Nessa cenografia, interagem três atores: Jesus, como convidado de honra, o fariseu Simão, como anfitrião, e uma mulher, que invade a cenografia tradicional do jantar, lavando e ungindo os pés de Jesus enquanto ele está reclinado à mesa. Para compreender a cenografia construída pelo enunciador, é fundamental recorrermos às condições sócio-históricas e culturais de produção desse discurso. Na época do Novo Testamento, jantares eram oferecidos, colocando-se no centro da sala uma mesa de madeira muito baixa, quase rente ao chão, onde eram colocados os pratos oferecidos aos participantes. Pequenos divãs eram postos ao redor da mesa. Os convidados serviam-se reclinando sobre os divãs, com os pés para trás, afastados da mesa. Os empregados da casa ficavam por trás dos convidados e as portas da casa ficavam abertas, oferecendo a oportunidade de qualquer pessoa "assistir" ao jantar, atrás dos empregados.

A partir do recorte 40, fica evidenciado o processo de metaenunciação instaurado. O enunciador se vale da voz de Jesus e estabelece uma nova cenografia, a qual denominamos pedagógico-profética. Ao utilizar a voz de Jesus, o enunciador busca validar os seus enunciados, conferindo-lhes uma autoridade peculiar. As palavras na voz de Jesus são mais aptas para garantir a adesão dos atores na cenografia, uma vez que o enunciador diz exatamente aquilo que gostaria de dizer ao fariseu, que representa ali toda a elite religiosa judaica do seu tempo. Essa metaenunciação torna-se parte constitutiva do processo criador em Lucas, uma vez que ele ocupa a posição paratópica de ser, ao mesmo tempo, um homem mortal, mas, também, aquele através do qual deve manifestar-se a voz divina. 
O enunciador constrói a cenografia em forma de uma sequência narrativa, na qual são apresentados três interlocutores: um credor e dois devedores. A relação entre eles estabelece uma conexão entre os conceitos de perdão e amor, relacionando o ato de perdoar ao amor que é retribuído por aquele que se vê perdoado, conforme vemos nos recortes (41) e (42):

41 Certo credor tinha dois devedores: um the devia quinhentos denários, e o outro, cinquenta.

42 Não tendo nenhum dos dois com que pagar, perdoou-lhes a ambos. Qual deles, portanto, o amará mais?

O enunciador, através da voz de Jesus, se utiliza de um recurso pedagógico, a fim de mostrar o valor do perdão ao fariseu. Ele parte de uma medida de valor objetiva, o denário, uma moeda romana cunhada em prata e que correspondia à diária de um trabalhador na lavoura, para conduzir o fariseu a estabelecer uma relação de valor em questões subjetivas e sociais, como o perdão e o amor. A sequência de enunciados pode ser assim resumida: A ambos os devedores deviam uma alta soma em dinheiro; B - um devia dez vezes mais do que o outro; $\mathrm{C}$ - ambos não tinham como pagar; D - ambos foram perdoados de suas dívidas. A pergunta final: “Qual deles, portanto, o amará mais?" Leva o fariseu a estabelecer a relação entre perdão e amor, conforme vemos no recorte 43: "Respondeu-lhe Simão: Suponho que aquele a quem mais perdoou. Replicou-lhe: Julgaste bem".

A cenografia pedagógico-profética continua. O enunciador, na voz de Jesus, se utiliza da metáfora dos dois devedores para trazer 
uma exortação diretamente relacionada aos líderes religiosos da época, representados ali pelo fariseu. $\mathrm{O}$ desenvolvimento da cenografia mostra que os dois atores que interagem com Jesus estão representados na metáfora. A mulher, considerada socialmente pecadora, e o fariseu, considerado socialmente justo, mas que, aos olhos do enunciador, também se mostra pecador. Ambos possuem uma dívida impagável. A fim de estabelecer essa relação, o enunciador recupera as ações praticadas pela mulher, mostrando que ela, considerada pecadora, havia agido corretamente, enquanto o fariseu, considerado justo, havia pecado em suas ações.

Para compreender a relação estabelecida entre o comportamento do fariseu e da mulher, é preciso, mais uma vez, recuperarmos as condições sócio-históricas de produção do discurso. Segundo Bailey (1995), o ritual da boa hospitalidade no Oriente Médio, à época do Novo Testamento, estipulava duas regras fundamentais de cortesia, quando se convidava alguém para um jantar: em primeiro lugar, os servos da casa deveriam lavar os pés do visitante, logo na chegada; em segundo lugar, o anfitrião receberia o convidado com um abraço afetuoso e um beijo de saudação. No caso de o convidado ser uma autoridade religiosa ou civil, como um rabi ou um centurião, existia ainda uma terceira cortesia comum: derramar sobre sua cabeça algum tipo de perfume. Essas regras só eram dispensadas, quando o anfitrião recebia alguém de uma condição social muito inferior. $\mathrm{O}$ enunciador estabelece um paralelismo entre as ações da mulher e do fariseu, mostrando, assim, que o fariseu violara todas as regras fundamentais da boa hospitalidade. $\mathrm{O}$ paralelismo entre a atitude dos dois é feito de forma explícita, como vemos nos recortes 44, 45 e 46. 
44 não me deste água para os pés; esta, porém, regou os meus pés com lágrimas e os enxugou com os seus cabelos.

45 Não me deste ósculo; ela, entretanto, desde que entrei não cessa de me beijar os pés.

46 Não me ungiste a cabeça com óleo, mas esta, com bálsamo, ungiu os meus pés.

Essa exortação pública soava constrangedora para o fariseu, principalmente porque uma mulher, minoria social, estava sendo colocada numa posição mais elevada do que a dele. Na sequência, o enunciador, na voz de Jesus, recupera a narrativa dos dois devedores, quando torna clara a aplicação da metáfora tanto ao fariseu quanto à mulher. Ele utiliza o próprio dito do fariseu, que havia concluído que aquele que tinha a dívida maior e, portanto, recebera um maior perdão, deveria manifestar maior amor para com o credor, que lhe oferecera perdão, e faz a aplicação direta em relação à mulher: aquele que muito ama, muito é perdoado: (47) "Por isso, te digo: perdoados lhe são os seus muitos pecados, porque ela muito amou"; e também faz a aplicação ao fariseu, mostrando que aquele que pouco é perdoado, pouco ama: "[...] mas aquele a quem pouco se perdoa, pouco ama".

Aqui, o enunciador constrói um ethos que deifica o sujeito Jesus, colocando-o numa posição de alguém que está acima até mesmo dos próprios profetas; afinal, o atributo de perdoar pecados só pode ser assumido pelo próprio Deus. Nesse ponto, o enunciador informa a perplexidade que o enunciado dito por Jesus causara naquele ambiente social: (49) "Quem é este que até perdoa pecados?” Esta é uma pergunta de caráter retórico-argumentativo, na medida em que a resposta está implícita: só Deus pode perdoar pecados; se Jesus se coloca na posição de alguém que perdoa peca- 
dos, logo, ele é Deus. O ethos que deifica o sujeito Jesus é ratificado no enunciado final, quando ele assume não só o poder de perdoar pecados, como de salvar a alma daquela mulher, conforme recorte (50) "Mas Jesus disse à mulher: A tua fé te salvou; vai-te em paz".

Entendemos, portanto, que o discurso "Os Dois Devedores", se constitui a partir da posição paratópica de Lucas, o hagiógrafo, que instaura um processo de metaenunciação, assumindo a voz de Jesus, a fim de garantir a adesão dos seus co-enunciadores. Esse processo estabiliza toda a construção enunciativa, uma vez que o discurso se situa na fronteira entre o divino e o humano, permitindo a Lucas, através de uma cenografia pedagógico-profética, confrontar os líderes religiosos da época e, ao mesmo tempo, transmitir o ensino de valores fundamentais ao cristianismo, como perdão e amor.

\section{Conclusão}

Nossos resultados apontam para uma paratopia criadora, como pertencimento e o não pertencimento, visto que o produtor do discurso constituinte teológico se encontra em um lugar que não é o seu. Através do processo de metaenunciação, percebemos que Lucas opera, no discurso, como aquele que o organiza e dá voz aos interlocutores, que interagem em cada cenografia, seja a voz de Jesus, dos líderes religiosos da época ou de grupos sociais que interagem no interior do discurso. Além disso, revela um ethos discursivo que se legitima em uma cenografia que desloca um enunciador, cuja fala advém de outro lugar, que não é dele mesmo, mas de uma fonte legitimadora, um hiperenunciador, que valida todo o discurso teológico. 


\section{Referências}

AUTHIER-REVUZ, Jacqueline. Heterogeneidade(s) enunciativas(s). In: Cadernos de Estudos Linguísticos. Campinas: Unicamp, 1990, p. 25-42.

BAKHTIN, Mikhail. Gêneros do Discurso. In: BAKHTIN, Mikhail. Estética da criação verbal. 3. ed. São Paulo: Martins Fontes, 2000. p. 279-326.

BÍBLIA SAGRADA. Português. Bíblia Shedd. Versão Almeida Revista e Atualizada - SBB. São Paulo: Vida Nova, 1998.

BRUCE, F. F. Paulo: $o$ apóstolo da graça, sua vida, cartas e teologia. São Paulo: Shedd Publicações, 2003.

BRUCE, F. F. Bíblia. In: O NOVO DICIONÁRIO DA BÍBLIA. Tradução de João Bentes. 2. ed. São Paulo: Vida Nova, 1995. p. 219.

BAILEY, Kenneth. As parábolas de Lucas. São Paulo: Vida Nova, 1995.

BOURDIEU, Pierre. O Poder simbólico. Rio de janeiro: Bertrand Brasil S.A., 1989.

CAIRNS, Earle E. O cristianismo através dos séculos: uma história da Igreja cristã. São Paulo: Vida Nova, 1995.

CARSON, D. A.; MOO, D. J.; MORRIS, L. Introdução ao Novo Testamento. São Paulo: Vida Nova, 1997.

CESARÉIA, Eusébio de. História eclesiástica: os primeiros quatro séculos da Igreja cristã. Rio de Janeiro: CPAD, 1999.

CHARAUDEAU, Patrick. Discurso político. São Paulo: Contexto, 2006.

CHARAUDEAU, Patrick; MAINGUENEAU, Dominique. Dicionário de análise do discurso. São Paulo: Contexto, 2014.

CHOMSKY, Noam. A Linguagem e a Mente. In: Novas perspectivas linguísticas. Petrópolis, RJ: Vozes, 1970. 
DAVIDSON, F. (org.). O novo comentário da Bíblia. São Paulo: Vida Nova, 1994.

DOUGLAS, J. D. (org.). O novo dicionário da Bíblia. Tradução de João Bentes. 2. ed. São Paulo: Vida Nova, 1995.

ELLISON, H. L. Fariseus. In: O NOVO DICIONÁRIO DA BÍBLIA. Tradução de João Bentes. 2. ed. São Paulo: Vida Nova, 1995. p. 604-605.

ERICKSON, Millard J. Introdução à Teologia sistemática. São Paulo: Vida Nova, 1997.

FILLION, Louis-Claude. Enciclopédia da vida de Jesus. Rio de Janeiro: Central Gospel, 2008.

FLORES, V.N.; BARBISAN, L.B.; FINATTO, M.J.B.; TEIXEIRA, M. Dicionário de linguística da enunciação. São Paulo: Contexto, 2009.

GADET, Françoise; HAK, Tony (org). Por uma análise automática do discurso: uma introdução à obra de Michel Pêcheux. Campinas, SP: Unicamp, 1997.

GELDENHUYS, J.N. O evangelho de Lucas. In: O NOVO DICIONÁRIO DA BÍBLIA. Tradução de João Bentes. 2. ed. São Paulo: Vida Nova, 1995. p. 964 e 966.

GINGRICH, F. W.; DANKER, F. W. Léxico do N.T. Grego/Português. São Paulo: Vida Nova, 1995.

GUNDRY, R. H. Panorama do Novo Testamento. São Paulo: Vida Nova, 1978.

GONÇALVES, João Batista Costa. A configuração discursiva do gênero parábola bíblica: entre a captação e a parafrasagem. In: Veredas On Line - Análise do Discurso - PPG Linguística/UFJF. Juiz de Fora-MG, 2010. p. 157-166.

HARRIS, R. L. (org.) Dicionário internacional de teologia do Antigo Testamento. São Paulo: Vida Nova, 1999.

JOSEFO, Flávio. História dos Hebreus. Rio de Janeiro: CPAD, 1990. 
KEVAN, E. F. O evangelho segundo S. Lucas. In: O NOVO COMENTÁRIO DA BÍBLIA. São Paulo: Vida Nova, 1994. p. 1027-1059.

LADD, G. E. Teologia do Novo Testamento. São Paulo: Exodus, 1997.

MAINGUENEAU, Dominique. Novas tendências em análise do discurso. Trad. Freda Indursky. Campinas, SP: Pontes, Unicamp, 1997.

MAINGUENEAU, Dominique. Analisando discursos constituintes. Revista do GELNE, v. 2, n. 1, 2000. p. 1-12.

MAINGUENEAU, Dominique. Análise de textos de comunicação. Tradução Cecília P. de Souza \& Délcio Rocha. São Paulo: Cortez, 2001.

MAINGUENEAU, Dominique. Gênese dos discursos. Tradução de Sírio Possenti. São Paulo: Parábola, 2005.

MAINGUENEAU, Dominique. Análise do discurso. REVEL - Revista Virtual de Estudos da Linguagem, v. 4, n. 6, março, 2006. p. 1-6.

MAINGUENEAU, Dominique. A Análise do Discurso e suas fronteiras. Matraga, Rio de Janeiro, v. 14, n. 20, 2007a. p. 13-37.

MAINGUENEAU, Dominique. Leituras e quadro hermenêutico. Filologia linguística portuguesa, n. 9, 2007b. p. 279-292.

MAINGUENEAU, Dominique. Polifonia e Cena de Enunciação na Pregação Religiosa. In: LARA, G.M.P.; MACHADO, I.L.; EMEDIATO, Wander. Análise do discurso hoje. São Paulo: Lucerna. 2007c, p. 199-218.

MAINGUENEAU, Dominique. Cenas da enunciação. Sírio Possenti; Maria Cecília Péres Souza-e-Silva (org.). São Paulo: Parábola, 2008.

MAINGUENEAU, Dominique. Discurso literário. Tradução de Adail Sobral. São Paulo: Contexto, 2009. 
MAINGUENEAU, Dominique. Doze conceitos em análise do discurso. Sírio Possenti; Maria Cecília Péres Souza-e-Silva (org.). São Paulo: Parábola, 2010.

MAINGUENEAU, Dominique. Frases sem texto. Tradução de Sírio Possenti. São Paulo: Parábola, 2014.

MAINGUENEAU, Dominique. Discurso e análise do discurso. Tradução de Sírio Possenti. São Paulo: Parábola, 2015.

MAINGUENEAU, Dominique. Retorno crítico sobre o ethos. In: BARONAS, R.L.; MESTI, P. C.; CARREON, R. O. Análise do Discurso: entorno da problemática do ethos, do político e de discursos constituintes. Campinas, SP: Pontes, 2016.

MILNE, Bruce. Estudando as doutrinas da Bíblia. São Paulo: ABU, 1996.

NASCIMENTO, Jarbas Vargas. O discurso religioso católico: um estudo linguístico do rito matrimonial. São Paulo: EDUC, 1993.

NASCIMENTO, Jarbas Vargas. et alii. A parábola do filho pródigo. São Paulo: LPB, 2009.

PACKER, J. I. Inspiração. In: O NOVO DICIONÁRIO DA BÍBLIA. 2. ed. Tradução de João Bentes. São Paulo: Vida Nova, 1995. p. 748-749.

POSSENTI, Sírio. Metaenunciação: uma questão de interdiscurso e de relevância. In: Revista de Estudos Linguísticos. Belo Horizonte - MG, 2000, v. 9, n. 1, p. 91-108.

RIENECKER, F.; ROGERS, C. Chave linguística do Novo Testamento grego. São Paulo: Vida Nova, 1995.

RUSHANSKY, Efraim. O palco da História: as raízes judaicas e o cristianismo. Jerusalém: T- Land, 2005.

SANOKI, Koichi. Parábola: um gênero literário. In: Reveleteo, Revista Eletrônica Espaço Teológico. São Paulo, 2013, vol. 7, n. 12, p. 102-112. 
SANT'ANNA, Marco Antônio Domingues. O gênero da parábola. São Paulo: UNESP, 2010.

STERN, David H. Comentário judaico do Novo Testamento. São Paulo: Atos, 2008.

THOMPSON, J. A. Sinédrio. In: O NOVO DICIONÁRIO DA BÎBLIA. Tradução de João Bentes. 2. ed. São Paulo: Vida Nova, 1995. p. 1535.

TORÁ. Português. Torá - A Lei de Moisés. ed. rev. e ampl. São Paulo: Sêfer, 2001. 